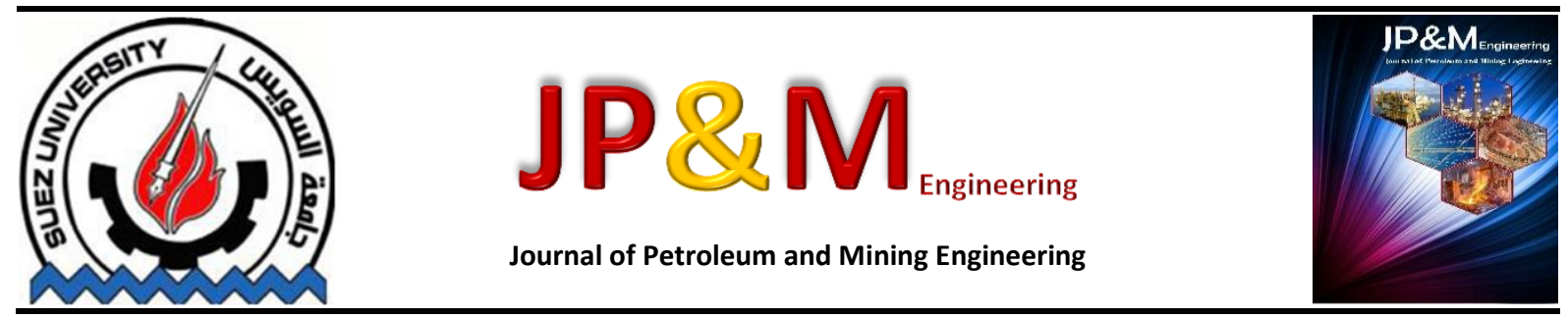

\title{
Process simulation and performance improving of a gas plant in operation
}

\author{
Ahmed A. Bhran ${ }^{a}$, Mohammed S. M. Saliem ${ }^{b}$, Galal M. Abdel-Aleim \\ a Suez University, Faculty of Petroleum and Mining Engineering, Petroleum Refining and Petrochemical Engineering Department, Suez, \\ Egypt. \\ ${ }^{\mathrm{b}}$ El-Wastani Petroleum Company, Damietta, Egypt.
}

\section{Keywords}

Natural gas liquids; NGL recovery improvements; Fuzzy logic.

\begin{abstract}
In the first part of this study, the natural gas liquids (NGLs) recovery enhancements techniques particularly by capacity increasing was studied to maximize the plant (EIWastani Petroleum Company located in Egypt) productivity and profitability. The present work studies new NGL recover enhancements routes based on the recovery maximization of butane, propane, or ethane as a final product for sales. The selection of the best improvement route is based on an economical and technical study of these various routes of improvements. This selection is done using fuzzy logic as an intelligent system for the process of decision making. According to the results of fuzzy logic system, it is noted that in spite of the capacity increasing mode have the highest return on investment (ROI), it is found that the maximization of propane recovery is the optimum route for the plant improvements. This is because the choice of propane recovery mode does not rely only on ROI but takes in consideration various objectives such as feed stability, marketing availability and recovered NGL quantity. The results of this research wok is beneficial for improving the NGL recovery plants in operation as well as the newly ones which should take in consideration these improvements modes before the plant design.
\end{abstract}

\section{Introduction}

The retrofitting of an existing NGL/LPG (liquefied petroleum gases) processing plant to use the latest technology allows expanding the plant capacity as discussed in details in an earlier research study [1]. Furthermore, this retrofitting allows correcting the limitations and deficiencies inherent in first and second generation process designs at the same time. Generally, this means that plant operations are more stable after the retrofit, making the plant easier to operate and optimize. Third generation NGL/LPG technology can be retrofit into nearly any existing first generation and second generation expander plant. It is proven that most of the existing plants can gain the advantages of the third generation technology, so that capacity is expanded, recovery efficiency is improved, plant operations are simplified, and recurring operating problems are eliminated [2]. A retrofit for increased ethane, propane or butane recovery alone is generally much simpler than one for both increased recovery and throughput because equipment sizing and pressure drop are less of a constraint. However, the economics of most NGL/LPG plants are improved if increases in both recovery and throughput can be achieved [3].
Recovery of NGLs components in gas not only may be required for hydrocarbon dew point control in a natural gas stream, but also yields a source of revenue, e.g., natural gas may include up to about fifty percent by volume of heavier hydrocarbons recovered as NGL. When designing a new plant or upgrading an existing plant it is very important to understand and select the right process to minimize capital and operating expenses. The process selection, complexity, and cost of the processing facility depend on the gas composition, inlet pressure to the gas plant, recovered product specifications and the extent of recovery that is desired. When market demand for ethane, propane, or propane is high, high recovery of ethane, propane or butane needs to be achieved in the gas plants respectively $[4,5]$.

Lower processing temperatures for higher recoveries of NGLs lead to increasingly complex and expensive refrigeration techniques. Numerous expansion processes are commonly used for hydrocarbon liquids recovery in the gas processing industry, particularly in the recovery of ethane and propane from high pressure feed gas. Recovering $90 \%$ and higher of the propane and over $70 \%$ of the ethane in natural gas streams typically requires temperatures in the -125 to -150 of region and lower $[6,7]$. NGL 
recovering processes from Natural Gas are generally based on one of the following or a combination of them: use of external refrigeration, turbo-expansion, Joule-Thompson-expansion, or absorption. As previously referred, each specific NGL recovery problem is characterized by a large number of variables, some of those include inlet pressure, residual gas and the top of the demethanizer column, duty of external refrigeration, power capacity of the turbo-expansion system, temperature and pressure of the cold tank and of the bottom of the demethanizer column [8]. Turbo-expanders are favored in applications where the pressure drop required for process operation is readily available of where recompression costs are of secondary economic importance [6]. Most of the gas plants in operation today use conventional single-stage turbo-expander technology for moderately high ethane recovery [9].
Five major NGLs - ethane, butane, iso-butane, propane and natural gasoline - are used by petrochemical companies as feed stocks and by refineries as blending and processing components. In areas where not enough natural gas processing capacity is available, gas production must be curtailed down to the available capacity but the process could be directed to increase its benefits through increasing the amount and quality of NGLs [10].

El Wastani plant located in Damietta, Egypt, is the plant on which the present study is conducted. ElWastani Petroleum Company (see Figure 1) operates wells network in order to process the feed gas stream to deliver sales gas, stabilized condensate, and liquefied petroleum gas (LPG) via central processing facilities (CPF) plant.

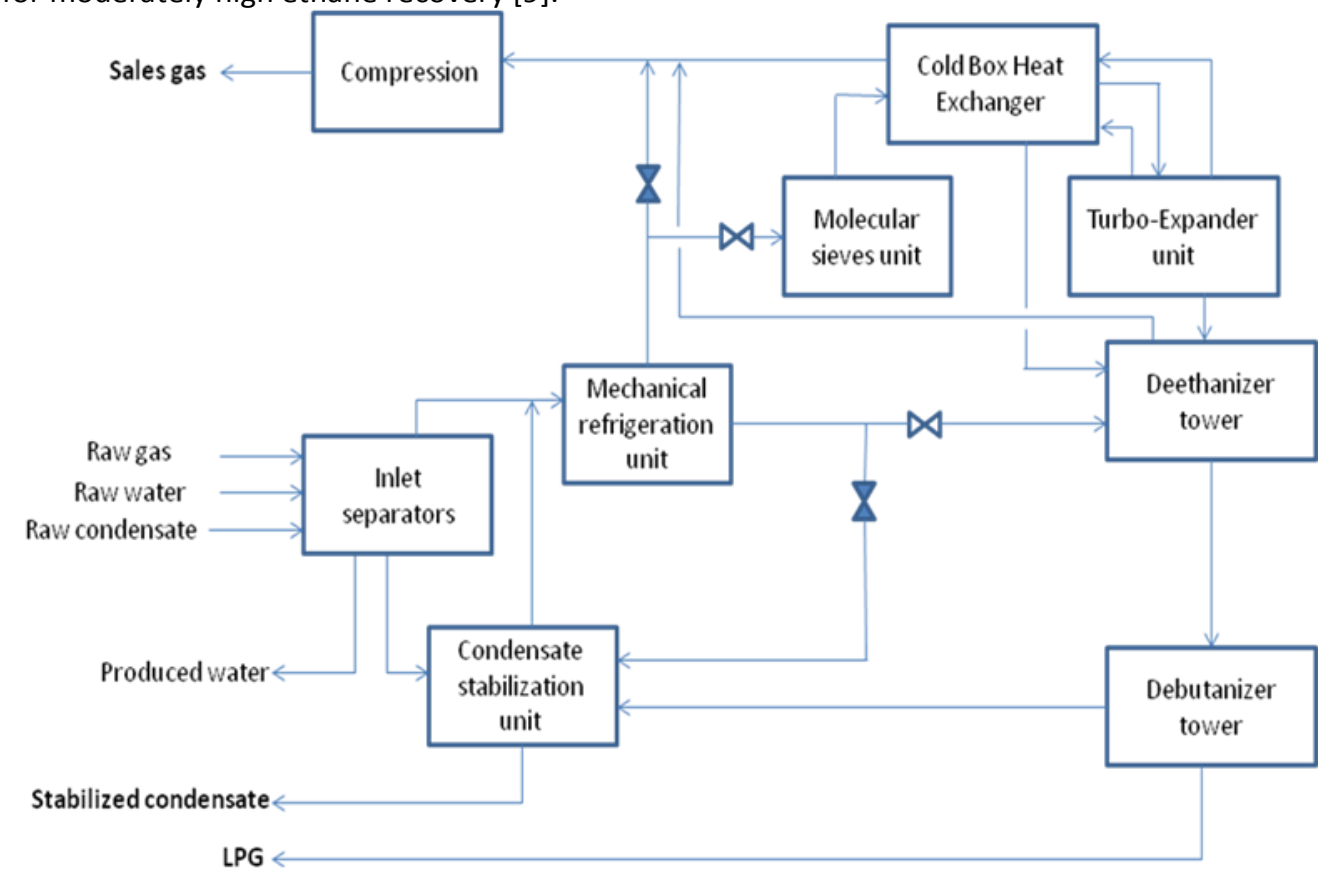

Figure 1 El-Wastani Central Processing Facilities Block Diagram.

Due to the rapid increasing of natural gas and NGL consumption, the need arises to enhance the performance of El-Wastani plant to get higher recovery level of NGLs as well as higher revenue. In the previous article [1] the route of feed gas capacity increase and its effect on performance and profitability of El-Wastani plant were studied. The present work is directed to study other alternative routes for improving the economics and efficiency of the plant. The new NGL recover enhancements routes are based on the recovery maximization of butane,

\section{Research Methodology}

The plan of this study is constructed as in the following steps:

- Studying the recovery maximization for ethane, propane, or butane by using HYSYS simulation. Cost estimation is performed and ROI is calculated for each recovery maximization route. propane, or ethane as a final product for sales. The selection of the best improvement route is based on an economical and technical study of these various routes of improvements. Methods of how to compare different processes are discussed, and optimization of a process to achieve the proper highest return on investment is presented. Each process is then simulated using HYSYS-3.2 which is based on PengRobinson equation of state for calculations [11]. The process configurations are developed from process flow diagram (PFD) and or piping and instrumentation diagram (P\&ID) information available in-house from EI Wastani plant.

- Studying of the effect of other alternative factors such as feed stability, marketing and total NGL quantity on the decision making process for selecting the optimum route via fuzzy logic technique.

- Determining of the optimum recovery mode and comparing it with the increasing capacity route. 


\section{Plant Feed Gas Chemical Composition}

As mentioned in the previous article [1], the most critical feed composition was the lean feed (low butanes) composition (see table 1) because it consumes higher energy than other feed composition. So, the improvement of the plant performance operated with the lean feed composition will ensure its performance improvements with other feed compositions.

Table 1 Lean feed gas compositions.

\begin{tabular}{|l|l|}
\hline Component & $\begin{array}{l}\text { Composition } \\
\text { in mole fraction }\end{array}$ \\
\hline Nitrogen & 0.0011 \\
\hline $\mathrm{CO}_{2}$ & 0.0047 \\
\hline Methane & 0.8808 \\
\hline Ethane & 0.0714 \\
\hline Propane & 0.0233 \\
\hline i-Butane & 0.0059 \\
\hline $\mathrm{n}$-Butane & 0.0046 \\
\hline i-Pentane & 0.0021 \\
\hline $\mathrm{n}$-Pentane & 0.0011 \\
\hline $\mathrm{n}$-Hexane & 0.0014 \\
\hline $\mathrm{n}$-Heptane & 0.0011 \\
\hline $\mathrm{n}$-Octane & 0.0006 \\
\hline $\mathrm{n}$-Nonane & 0.0002 \\
\hline $\mathrm{n}$-Decane & 0.0002 \\
\hline $\mathrm{H}$ - & 0.0015 \\
\hline Total & 1 \\
\hline & \\
\hline
\end{tabular}

\section{Equipment Sizing}

Equipment size is calculated by using the output data from Aspen Hysys simulation program to get the proper specification of the concerned equipment such as area with heat exchanger and power in the case of compressor, etc.

For example the exchanger area is calculated by using the duty given from Aspen Hysys. The log mean temperature difference is calculated for each re-boiler and condenser as follows:

Duty: $Q$ (given from Aspen HYSYS)

$\Delta t=L M T D=\frac{\Delta T_{1}-\Delta T_{2}}{\ln \left(\frac{\Delta T_{1}}{\Delta T_{2}}\right)}$

Where $\Delta t$ is the average temperature difference, LMTD is the log mean temperature difference. $\Delta T_{1}$ is the temperature difference between the hot inlet stream and cold outlet steam and $\Delta T_{2}$ is the difference between the hot outlet stream and the cold inlet stream. Area (A) of the equipment (condenser or reboiler) can be calculated from equation 2 .

$$
A=\frac{Q}{K \Delta t}
$$

(2)

Where $k$ is the thermal conductivity of the equipment material.

\section{Cost Estimation}

An estimate of the capital investment for a process may vary from a pre-design estimate based on little information to a detailed estimate prepared from complete drawings and specifications. These estimates are called by a variety of names, but there are five estimate categories represent the accuracy range and designation normally used for design purposes. These five famous estimates are order-ofmagnitude, study, preliminary, definitive and detailed estimates. The accuracy of these estimates are ranging from + or -30 to + or -5 percent respectively [12].

According to the current status of the plant (EI Wastani company) data availability and calculation stage, the preliminary estimate (budget authorization estimate) is applied. This choice is based on sufficient data used to permit the estimate to be budgeted. Probable accuracy of this estimate is within + or -20 percent.

\section{Fixed Capital Cost}

The fixed capital cost is estimated to get an approximate price for the total plant to be installed and running. In this present work, the calculations are based on a rule of thumb stated that the total fixed capital cost equals the purchased equipment cost multiplied by 2 [12].

Equipment costs are calculated according to cost estimation techniques where, the cost of the new equipment, $C_{n}$, is equal to the known equipment cost, $\mathrm{C}_{\mathrm{k}}$, times the ratio of the two plants' capacities raised to a fractional power as indicated in equation 3 .

$C_{n}=C_{k}\left(\frac{V_{n}}{V_{k}}\right)^{F}$

Where, $V_{n}$ is the capacity of the new plant, and $V_{k}$ is the capacity of the known plant. $F$ is a factor; usually take a value between 0.4 and 0.9 , depending on the type of plant. In the applied estimating technique, a factor value of 0.6 is used according to the literature or historical data [13]. In addition to use of NelsonFarrar indexes, the most proper approximated calculation could be performed to determine the value of the relevant cost at current time. This is done by the comparison with equipment prices which are obtained from El-Wastani Company [14].

\section{Working Capital Cost}

The working capital is the amount of capital required to start up the plant and to finance the first couple of months of operating before the plant starts earning. This capital is used to cover salaries, raw material inventories and contingencies. It will be recovered at the end of the project and represents a float of money to get the project started. These costs are necessary at start-ups and it implies raw materials and intermediates in the process. The working capital cost is assumed to be $3 \%$ of the fixed capital cost [15].

\section{Operating Cost}

The operating cost includes all the incremental increase in cost due to chemical injection, power, treatment, and utility consumption which is needed to achieve the required target of increasing capacity or recovery maximization of ethane, propane, or butane.

\section{Investment Analysis Technique}

The results obtained from the simulator for each modification route are analyzed by two different techniques; return on investment and Intelligent System Technique (Fuzzy Logic). 


\section{Return on Investment}

The determination and analysis of profits obtainable from the total cost of investment and the choice of the best investment among various alternatives are major goals of the investment analysis. Values from 20 to 30 percentages for ROI can be used as a rough guide for judging the plant retrofitting. Consequently, the decision has to be made on whether to install additional equipment to reduce operating costs or not $[12,16]$.

The calculations of ROI are mainly consisting of the following two major terms:

- Total capital investment which includes the cost of purchased equipment, installation and foundation, instrumentation, piping, and commissioning works.

- The net profit which is resulting via productivity increase after excluding the annual increase in operating cost.

$R O I=\frac{\text { (Total anmual income increment-annual increase in operating cost) }}{\text { Total capital investement }}(4)$

The total capital investment includes the fixed capital cost in addition to the working capital cost. Pay-back period which is the period of time required for the return on an investment to "repay" the sum of the original investment can be calculated as bellow:

Pay back period $=1 /$ ROI

\section{Intelligent System Technique (Fuzzy Logic)}

Fuzzy logic is a tool for transforming human knowledge and its decision-making ability into a mathematical formula. In other words, it provides a meaningful and powerful representation of measurement uncertainties and also a meaningful representation of vague concepts expressed in natural language. In any decision-making process it is necessary to evaluate different alternatives and discard those that do not fit certain previously established criteria [17-19].

For a finite set $A$ of $n$ alternatives and a given system of $m$ evaluation criteria $f_{i}$, the multi criteria problem in its general form can be defined as follows:

$\operatorname{Max}\left\{f_{1}(a), f_{2}(a), \ldots . ., f_{m}(a) / a \varepsilon A\right\}$

For every criterion $f_{j}$ of the multi-criteria problem, a membership function $x_{j}$ is defined and takes values to the interval $[0,1]$. This transformation is based on the concept of the ideal point. So, the value $x_{a j}$ represented by equation 7 expresses the degree to which the alternative " $a$ " is close to the ideal value $f_{j}{ }^{*}$ (the best performance in criterion $\mathrm{j}$ ) and far from the anti-ideal value $\mathrm{f}_{\mathrm{j}}^{* *}$ (the worst performance in criterion j) [20-22]:

$X a j=\frac{f j(a)-f j * *}{f j *-f j * *}$

Many simple decision processes are based on a single objective, such as maximizing profit, minimizing run time, and so forth. Besides the capacity increase route (as an objective), there are other many alternatives which can improve the investigated plant performance such as:

- Feed stability continuity.

- Marketing concerns and shipping availability.

- Return on investment; including cost and profit individually.

- Recovered NGL productivity.

Define universe of " $r$ " alternatives:

$\mathrm{O}=\left\{\mathrm{O}_{1}, \mathrm{O}_{2}, \ldots ., \mathrm{Or}\right\}$

Let $\mathrm{O}_{\mathrm{i}}$ indicate the $\mathrm{i}^{\text {th }}$ objective. Then the degree of membership of an alternative " $a$ " in $\mathrm{O}_{\mathrm{i}}$, denoted $\mu_{\mathrm{oi}}(\mathrm{a})$. The decision function, $\mathrm{D}$, that simultaneously satisfies all of the decision objectives is given by the intersection of all the objectives sets as indicated in the following equation:

$\mathrm{D}=\mathrm{O}_{1} \cap \mathrm{O}_{2} \cap \ldots . . . \cap \mathrm{O}_{\mathrm{r}}$

Therefore, the grades of membership that the decision function, D, has for each alternative "a" is given by:

$\mu_{D}(a)=\min \left[\mu_{\mathrm{o} 1}(a), \mu_{\mathrm{o} 2}(a), \ldots \ldots, \mu_{\mathrm{or}}(a)\right]$

The optimum decision, " $a$ ", will then be the alternative that satisfies the following equation [2026]:

$$
\mu_{D}\left(a^{*}\right)=\max _{a \varepsilon A}\left(\mu_{D}(a)\right)
$$

\section{Results and Discussion}

The performance of El Wastani plant for high recovery of NGL components is studied at 160 MMSCFD as a feed gas capacity with lean feed gas composition (as listed in table 1). High butane, propane or ethane recovery routes are studied for 96 $\%$ recovery for each route.

Expansion efficiency is thermodynamically a function of temperature. Therefore, the inlet temperature to the expander is critical to the determination of the expander performance [27]. Expanders are known to be applied at the lowest temperature levels of configurations, as this where they are thermodynamically more efficient [28, 29]. So, the modification and the additional requirement should be arranged for refrigeration and separation in the original scheme.

\section{Butane Recovery Mode}

The installation of an additional refrigeration package is required to achieve the high recovery (96\%) of butane. The major areas which need revamping are as the following:

- Mechanical refrigeration unit to allow lowering the temperature of the chiller in order to condense the targeted level of butane.

- Condensate stabilization unit to recover all the butanes to maximize the LPG quantity.

- Fractionation train in particular the de-ethanizer tower to handle the additional light gases due to the low temperature process and topped the feed to de-butanizer tower. 
Table 2 exhibits the composition analysis of the inlet and outlet gas after and before the plant revamping.

Table 2 Feed and sale gas analysis before and after

\begin{tabular}{|c|c|c|c|c|c|c|}
\hline \multirow[b]{3}{*}{ Component } & \multirow{2}{*}{\multicolumn{2}{|c|}{ Feed Gas }} & \multicolumn{4}{|c|}{ Sale Gas } \\
\hline & & & \multicolumn{2}{|c|}{ Before } & \multicolumn{2}{|c|}{ After } \\
\hline & $\begin{array}{c}\text { Mole } \\
\text { fraction }\end{array}$ & $\begin{array}{c}\text { Mass flow } \\
(\mathrm{kg} / \mathrm{h})\end{array}$ & $\begin{array}{c}\text { Mole } \\
\text { fraction }\end{array}$ & $\begin{array}{c}\text { Mass flow } \\
(\mathrm{kg} / \mathrm{h})\end{array}$ & $\begin{array}{c}\text { Mole } \\
\text { fraction }\end{array}$ & $\begin{array}{c}\text { Mass flow } \\
(\mathrm{kg} / \mathrm{h})\end{array}$ \\
\hline Nitrogen & 0.0011 & 245 & 0.001 & 223 & 0.0011 & 245 \\
\hline $\mathrm{CO}_{2}$ & 0.0047 & 1645 & 0.0042 & 1426 & 0.0048 & 1639 \\
\hline Methane & 0.8771 & 112616 & 0.9134 & 114131 & 0.9083 & 112616 \\
\hline Ethane & 0.0711 & 17114 & 0.0659 & 15435 & 0.0736 & 17114 \\
\hline Propane & 0.0232 & 8186 & 0.0126 & 4322 & 0.012 & 4076 \\
\hline i-Butane & 0.0063 & 2950 & 0.0019 & 841 & 0.0001 & 43 \\
\hline n-Butane & 0.0049 & 2300 & 0.0009 & 411 & 0 & 11 \\
\hline i-Pentane & 0.0021 & 1224 & 0.0001 & 69 & 0 & 0 \\
\hline n-Pentane & 0.0011 & 654 & 0 & 20 & 0 & 0 \\
\hline n-Hexane & 0.0014 & 967 & 0 & 2 & 0 & 0 \\
\hline n-Heptane & 0.0012 & 925 & 0 & 0 & 0 & 0 \\
\hline n-Octane & 0.0006 & 559 & 0 & 0 & 0 & 0 \\
\hline n-Nonane & 0.0002 & 203 & 0 & 0 & 0 & 0 \\
\hline n-Decane & 0.0002 & 184 & 0 & 0 & 0 & 0 \\
\hline $\mathrm{H}_{2} \mathrm{O}$ & 0.003 & 436 & 0 & 0 & 0 & 0 \\
\hline Ethylene Glycol & 0.0018 & 873 & 0 & 0 & 0 & 0 \\
\hline Total & 1 & 151082 & 1 & 136881 & 1 & 135745 \\
\hline
\end{tabular}

Table 3 Simulation results for butane recovery mode.

\begin{tabular}{|c|c|c|c|c|}
\hline \multicolumn{2}{|c|}{ PARAMETER } & Unit & Design & Simulated \\
\hline \multicolumn{2}{|c|}{ Gas rate } & MMSCFD & 160 & 160 \\
\hline \multicolumn{2}{|c|}{ Glycol re-boiler duty } & MMBtu/h & 1 & 0.9147 \\
\hline \multicolumn{2}{|c|}{ Glycol injection rate } & $\mathrm{M} 3 / \mathrm{H}$ & 1.158 & 1.037 \\
\hline \multicolumn{2}{|c|}{ Gas/gas heat exchanger } & MMBtu/h & 15.57 & 18 \\
\hline \multicolumn{2}{|c|}{ MRU chiller } & $\mathrm{MMBtu} / \mathrm{h}$ & 6.7 & 15.4 \\
\hline \multicolumn{2}{|c|}{ Mole Sieve } & MMSCFD & 162.000 & 152.400 \\
\hline \multicolumn{2}{|c|}{ Cold Box } & MMBtu/h & 12.80 & 12.83 \\
\hline \multirow{2}{*}{ Turbo Expander } & Power & $\mathrm{hp}$ & Max. 1165 & 1165.000 \\
\hline & Gas rate & MMSCFD & Max. 190.8 & 137.000 \\
\hline \multirow{4}{*}{ De-Ethanizer tower } & Condenser duty & MMBtu/h & 1.435 & 5.582 \\
\hline & Re-boiler duty & MMBtu/h & 8.440 & 17.85 \\
\hline & Compressor power & $\mathrm{hp}$ & 200 & 274.3 \\
\hline & Compressor quantity & MMSCFD & 12.01 & 30.9 \\
\hline \multirow{2}{*}{ De-Butanizer tower } & Condenser duty & MMBtu/h & 8.458 & 4.787 \\
\hline & Re-boiler duty & MMBtu/h & 6.835 & 3.565 \\
\hline \multirow{4}{*}{$\begin{array}{c}\text { Condensate } \\
\text { Stabilizer tower }\end{array}$} & Condenser duty & MMBtu/h & 5.962 & 5.676 \\
\hline & Re-boiler duty & MMBtu/h & 7.880 & 5.456 \\
\hline & Compressor power & $\mathrm{hp}$ & 530.000 & 219.300 \\
\hline & Compressor quantity & MMSCFD & 2.710 & 1.506 \\
\hline \multirow{2}{*}{$\begin{array}{c}\text { Sale gas boosting } \\
\text { compressor }\end{array}$} & Power & $\mathrm{hp}$ & 11000 & 6778 \\
\hline & Quantity & MMSCFD & 193.32 & 155.7 \\
\hline
\end{tabular}

Table 4 Plant Production quantities at butane recovery mode.

\begin{tabular}{|c|c|c|c|c|}
\hline Raw Gas Rate & Sales Gas & \multicolumn{2}{|c|}{ Sales LPG } & Sales Condensate \\
\cline { 3 - 5 } MMSCFD & MMSCFD & Ton/day & Recovery \% & BBLy day \\
\hline 160 & 155.2 & 230.1 & 96.05 & 4052 \\
\hline
\end{tabular}

Table 3 presents the simulation results of the plant. The incremental percentage and the perspective quantities to be obtained after perform the proposed modification, are tabulated in table 4 . Table 5 summarizes all needed economic data to have a viable revamp alternative. 
In order to achieve $96 \%$ propane recovery, an additional refrigeration package as well as a depropanizer package are required to be installed for sustaining an adequate separation of propane as a commercial product with desired specifications. This is accomplished by calculating and fulfilling all the requirements for each additional equipment.

The major areas which need revamping are as the following:

- Mechanical refrigeration unit to allow lowering the temperature of the chiller in order to condense the targeted level of butane \& propane.

- Fractionation train:-

- In particular the de-ethanizer tower to handle the additional light gases due to the low temperature process and topped the feed to de-butanizer tower.

- Adding de-propanizer tower to handle the deethanizer re-boiler outlet prior to de-butanizer tower and accomplish the required on spec commercial propane.

- Revamp plate and fin heat exchange to handle and utilize the excess energy due to the extra refrigeration power.

Table 6, presents the simulation results of the plant and Table 7 exhibits the composition analysis of the inlet and outlet gas after and before the plan revamping. While the incremental percentage and the

perspective quantities to be obtained after performing the proposed modification, are tabulated in Table 8. Table 9 summarizes all needed economic data to have a viable revamp alternative.

\section{Ethane Recovery Mode}

For obtaining $96 \%$ ethane recovery, it is required to install additional refrigeration package as well as installing the following packages:

- De-methanizer unit package.

- De-ethanizer additional tower to fulfill the increasing of condensed hydrocarbons.

- De-propanizer unit package.

To sustain adequate separation of propane as a commercial product with the desired specifications, this target is accomplished by calculating and fulfilling all the requirements for each additional package. The major areas which will be modified are mechanical refrigeration unit, molecular sieve unit for dehydration, cold box unit, and Fractionation train.

Table 5 Economic study results for butane recovery mode

\begin{tabular}{|l|l|}
\hline Fixed Capital Investment, MM\$ & 24.3 \\
\hline Operating Cost, MM\$ & 3.2 \\
\hline Total Capital Investment, MM\$ & 25 \\
\hline Revenue, MM\$ & 366 \\
\hline Increment, MMS & 17.11 \\
\hline ROI (return on investment), \% & 56 \\
\hline Pay-Back Time, Years & 1.8 \\
\hline
\end{tabular}

Table 6 Simulation results for propane recovery mode.

\begin{tabular}{|c|c|c|c|c|}
\hline \multicolumn{2}{|l|}{ PARAMETER } & Unit & Design & Simulated \\
\hline \multicolumn{2}{|l|}{ Gas rate } & MMSCFD & 160 & 160 \\
\hline \multicolumn{2}{|c|}{ Glycol re-boiler duty } & MMBtu/ & 1 & 0.9513 \\
\hline \multicolumn{2}{|c|}{ Glycol injection rate } & $\mathrm{M} 3 / \mathrm{H}$ & 1.158 & 1.040 \\
\hline \multicolumn{2}{|c|}{ Gas/gas heat exchanger } & MMBtu/ & 15.57 & 18.650 \\
\hline \multicolumn{2}{|c|}{ MRU chiller } & MMBtu/ & 6.7 & 19.98 \\
\hline \multicolumn{2}{|l|}{ Mole sieve } & MMSCFD & 162.000 & 145.1 \\
\hline \multicolumn{2}{|l|}{ Cold Box } & MMBtu/ & 12.80 & 10.41 \\
\hline \multirow[t]{2}{*}{ Turbo Expander } & Power & $\mathrm{hp}$ & Max. & 1165 \\
\hline & Gas rate & MMSCFD & Max. & 132.4 \\
\hline \multirow{4}{*}{$\begin{array}{l}\text { De-ethanizer } \\
\text { tower }\end{array}$} & Condenser duty & MMBtu/ & 1.435 & 11.03 \\
\hline & Re-boiler duty & MMBtu/ & 8.440 & 22.47 \\
\hline & Compressor power & $\mathrm{hp}$ & 200 & 280 \\
\hline & Compressor & MMSCFD & 12.01 & 36.5 \\
\hline \multirow{2}{*}{$\begin{array}{l}\text { De-propanizer } \\
\text { tower }\end{array}$} & Condenser duty & MMBtu/ & - & 18.84 \\
\hline & Re-boiler duty & MMBtu/ & - & 18.63 \\
\hline \multirow{2}{*}{$\begin{array}{l}\text { De-butanizer } \\
\text { tower }\end{array}$} & Condenser duty & MMBtu/ & 8.458 & 5.13 \\
\hline & Re-boiler duty & MMBtu/ & 6.835 & 4.616 \\
\hline \multirow{4}{*}{$\begin{array}{c}\text { Condensate } \\
\text { Stabilizer tower }\end{array}$} & Condenser duty & MMBtu/ & 5.962 & 5.845 \\
\hline & Re-boiler duty & MMBtu/ & 7.880 & 5.422 \\
\hline & Compressor power & $\mathrm{hp}$ & 530.000 & 218.6 \\
\hline & Compressor & MMSCFD & 2.710 & 1.501 \\
\hline \multicolumn{2}{|l|}{ Hot oil system } & MMBtu/ & 32 & 52.089 \\
\hline \multirow{2}{*}{$\begin{array}{l}\text { Sale gas boosting } \\
\text { Compressor }\end{array}$} & Power & $\mathrm{hp}$ & 11000 & 6973 \\
\hline & Quantity & MMSCFD & 193.32 & 153.4 \\
\hline
\end{tabular}

Table 10, presents the simulation results of the plant for the ethane recovery mode while Table 11shows the composition and flow rates of the inlet and outlet gas after and before the plant revamp. The incremental percentage and the perspective quantities to be obtained after performing the proposed modification are tabulated in Table 12. 
Table 13 summarizes all needed economic data required to have that possible revamp alternative.

Table 7 Feed and sale gas analysis before and after plant revamp for propane recovery mode.

\begin{tabular}{|c|c|c|c|c|c|c|}
\hline \multirow[b]{3}{*}{ Component } & \multirow{2}{*}{\multicolumn{2}{|c|}{ Feed Gas }} & \multicolumn{4}{|c|}{ Sale Gas } \\
\hline & & & \multicolumn{2}{|c|}{ Before } & \multicolumn{2}{|l|}{ After } \\
\hline & $\begin{array}{l}\text { Mole } \\
\text { fraction }\end{array}$ & $\begin{array}{l}\text { Mass } \\
\text { flow } \\
(\mathrm{kg} / \mathrm{h})\end{array}$ & $\begin{array}{l}\text { Mole } \\
\text { fraction }\end{array}$ & $\begin{array}{l}\text { Mass } \\
\text { flow } \\
(\mathrm{kg} / \mathrm{h})\end{array}$ & $\begin{array}{l}\text { Mole } \\
\text { fraction }\end{array}$ & $\begin{array}{l}\text { Mass } \\
\text { flow } \\
(\mathrm{kg} / \mathrm{h})\end{array}$ \\
\hline Nitrogen & 0.0011 & 245 & 0.001 & 223 & 0.0011 & 245 \\
\hline $\mathrm{CO}_{2}$ & 0.0047 & 1645 & 0.0042 & 1426 & 0.0049 & 1638 \\
\hline Methane & 0.8771 & 112616 & 0.9134 & 114131 & 0.9185 & 112616 \\
\hline Ethane & 0.0711 & 17114 & 0.0659 & 15435 & 0.0745 & 17114 \\
\hline Propane & 0.0232 & 8186 & 0.0126 & 4322 & 0.0009 & 310 \\
\hline i-Butane & 0.0063 & 2950 & 0.0019 & 841 & 0 & 13 \\
\hline n-Butane & 0.0049 & 2300 & 0.0009 & 411 & 0 & 4 \\
\hline i-Pentane & 0.0021 & 1224 & 0.0001 & 69 & 0 & 0 \\
\hline n-Pentane & 0.0011 & 654 & 0 & 20 & 0 & 0 \\
\hline n-Hexane & 0.0014 & 967 & 0 & 2 & 0 & 0 \\
\hline n-Heptane & 0.0012 & 925 & 0 & 0 & 0 & 0 \\
\hline n-Octane & 0.0006 & 559 & 0 & 0 & 0 & 0 \\
\hline n-Nonane & 0.0002 & 203 & 0 & 0 & 0 & 0 \\
\hline n-Decane & 0.0002 & 184 & 0 & 0 & 0 & 0 \\
\hline $\mathrm{H}_{2} \mathrm{O}$ & 0.003 & 436 & 0 & 0 & 0 & 0 \\
\hline Ethylene Glycol & 0.0018 & 873 & 0 & 0 & 0 & 0 \\
\hline Total & 1 & 151082 & 1 & 136881 & 1 & 131941 \\
\hline
\end{tabular}

Table 8 Plant Production quantities for Propane Recovery Mode.

\begin{tabular}{|c|c|c|c|c|c|c|}
\hline \multirow{2}{*}{$\begin{array}{c}\text { Raw Gas Rate } \\
\text { MMSCFD }\end{array}$} & \multirow{2}{*}{$\begin{array}{l}\text { Sales Gas } \\
\text { MMSCFD }\end{array}$} & \multicolumn{2}{|c|}{ Sales propane } & \multicolumn{2}{|c|}{ Sales LPG } & \multirow{2}{*}{$\begin{array}{c}\text { Sales Condensate } \\
\text { BBLS/day }\end{array}$} \\
\hline & & Ton/day & Recovery \% & Ton/day & Recovery \% & \\
\hline 160 & 153.4 & 189.9 & 96.00 & 128.1 & 96.00 & 4080 \\
\hline
\end{tabular}

Table 9 Economic study results for propane recovery mode.

\begin{tabular}{|c|c|}
\hline Fixed Capital Investment, MM\$ & 41.14 \\
\hline Operating Cost, MM\$ & 3.38 \\
\hline Total Capital Investment, MM\$ & 42.37 \\
\hline Revenue, MM\$ & 408.02 \\
\hline Increment, MM\$ & 59.67 \\
\hline ROI (return on investment), \% & 133 \\
\hline Pay-Back Time, Years & 0.75 \\
\hline
\end{tabular}

\section{Decision Making Operation}

The process of optimization does not rely only on the economic route (ROI), but sometimes it is important to broaden the judgment basis. So, the aim of decision making is to find out the best possible course of action. It is a rational and purposeful activity designed to attain well-defined objectives, such as (feed stability, marketing availability, ROI, and recovered NGL quantity).

In the following section, all-related decision making steps such as data tabulation, fuzzy membership, ......, etc are performed.
In order to perform the procedure of fuzzy logic technique, the first step is the tabulation of the various values of alternatives' objectives. The following sections will exhibit as well as discuss the different parameters and ways of its evaluation. The different parameters are feed stability continuity, Marketing availability, Return on investment, and Recovered quantity of NGL. 
Table 10 Simulation results for the ethane recovery mode.

\begin{tabular}{|c|c|c|c|c|}
\hline \multicolumn{2}{|c|}{ PARAMETER } & Unit & Design & Simulated \\
\hline \multicolumn{2}{|c|}{ Gas rate } & MMSCFD & 160 & 160 \\
\hline \multicolumn{2}{|c|}{ Glycol re-boiler duty } & MMBtu/h & 1 & 1.051 \\
\hline \multicolumn{2}{|c|}{ Glycol injection rate } & $\mathrm{M} 3 / \mathrm{H}$ & 1.158 & 1.071 \\
\hline \multicolumn{2}{|c|}{ Gas/gas heat exchanger } & MMBtu/h & 15.57 & 12.26 \\
\hline \multicolumn{2}{|c|}{ MRU chiller } & MMBtu/h & 6.7 & 45.04 \\
\hline \multicolumn{2}{|c|}{ Mole sieve } & MMSCFD & 162.000 & 99.4 \\
\hline \multicolumn{2}{|c|}{ Cold Box } & MMBtu/h & 12.80 & 5.007 \\
\hline \multirow[t]{2}{*}{ Turbo Expander } & Power & $\mathrm{hp}$ & Max. 1165 & 1165 \\
\hline & Gas rate & MMSCFD & Max. 190.8 & 87.93 \\
\hline \multirow[t]{5}{*}{ De-methanizer tower } & Condenser duty & MMBtu/h & - & 17.38 \\
\hline & Re-boiler duty & MMBtu/h & - & 11.55 \\
\hline & Compressor power & $\mathrm{hp}$ & - & 431.6 \\
\hline & Compressor quantity & MMSCFD & - & 36.5 \\
\hline & Tower quantity & BPD & - & 42357 \\
\hline \multirow[t]{3}{*}{ De-ethanizer tower } & Condenser duty & MMBtu/h & 1.435 & 18.84 \\
\hline & Re-boiler duty & MMBtu/h & 8.440 & 22.47 \\
\hline & Tower quantity & BPD & 9528 & 12470 \\
\hline \multirow[t]{3}{*}{ De-propanizer tower } & Condenser duty & MMBtu/h & - & 18.84 \\
\hline & Re-boiler duty & MMBtu/h & - & 18.63 \\
\hline & Tower quantity & BPD & - & 4897 \\
\hline \multirow[t]{2}{*}{ De-butanizer tower } & Condenser duty & MMBtu/h & 8.458 & 5.13 \\
\hline & Re-boiler duty & MMBtu/h & 6.835 & 4.616 \\
\hline \multirow{4}{*}{$\begin{array}{c}\text { Condensate Stabilizer } \\
\text { tower }\end{array}$} & Condenser duty & MMBtu/h & 5.962 & 5.845 \\
\hline & Re-boiler duty & MMBtu/h & 7.880 & 5.456 \\
\hline & Compressor power & $\mathrm{hp}$ & 530.000 & 219.3 \\
\hline & Compressor quantity & MMSCFD & 2.710 & 1.501 \\
\hline \multicolumn{2}{|c|}{ Hot oil system } & MMBtu/h & 32 & 63.773 \\
\hline \multirow{2}{*}{$\begin{array}{c}\text { Sale gas boosting } \\
\text { Compressor }\end{array}$} & Power & $\mathrm{hp}$ & 11000 & 10250 \\
\hline & Quantity & MMSCFD & 193.32 & 140.8 \\
\hline
\end{tabular}

Table 11 Feed and sale gas analysis before and after plant revamp for ethane recovery mode

\begin{tabular}{|c|c|c|c|c|c|c|}
\hline \multirow[b]{3}{*}{ Component } & \multirow{2}{*}{\multicolumn{2}{|c|}{ Feed gas }} & \multicolumn{4}{|c|}{ Sale gas } \\
\hline & & & \multicolumn{2}{|c|}{ Before } & \multicolumn{2}{|c|}{ After } \\
\hline & $\begin{array}{c}\text { Mole } \\
\text { fraction }\end{array}$ & $\begin{array}{l}\text { Mass flow } \\
(\mathrm{kg} / \mathrm{h})\end{array}$ & $\begin{array}{c}\text { Mole } \\
\text { fraction }\end{array}$ & $\begin{array}{c}\text { Mass flow } \\
(\mathrm{kg} / \mathrm{h})\end{array}$ & $\begin{array}{c}\text { Mole } \\
\text { fraction }\end{array}$ & $\begin{array}{c}\text { Mass flow } \\
(\mathrm{kg} / \mathrm{h})\end{array}$ \\
\hline Nitrogen & 0.0011 & 245 & 0.001 & 223 & 0.0012 & 245 \\
\hline $\mathrm{CO}_{2}$ & 0.0047 & 1645 & 0.0042 & 1426 & 0.0039 & 1206 \\
\hline Methane & 0.8771 & 112616 & 0.9134 & 114131 & 0.991 & 112545 \\
\hline Ethane & 0.0711 & 17114 & 0.0659 & 15435 & 0.0039 & 823 \\
\hline Propane & 0.0232 & 8186 & 0.0126 & 4322 & 0 & 14 \\
\hline i-Butane & 0.0063 & 2950 & 0.0019 & 841 & 0 & 0 \\
\hline n-Butane & 0.0049 & 2300 & 0.0009 & 411 & 0 & 0 \\
\hline i-Pentane & 0.0021 & 1224 & 0.0001 & 69 & 0 & 0 \\
\hline n-Pentane & 0.0011 & 654 & 0 & 20 & 0 & 0 \\
\hline $\mathrm{n}$-Hexane & 0.0014 & 967 & 0 & 2 & 0 & 0 \\
\hline n-Heptane & 0.0012 & 925 & 0 & 0 & 0 & 0 \\
\hline n-Octane & 0.0006 & 559 & 0 & 0 & 0 & 0 \\
\hline n-Nonane & 0.0002 & 203 & 0 & 0 & 0 & 0 \\
\hline n-Decane & 0.0002 & 184 & 0 & 0 & 0 & 0 \\
\hline $\mathrm{H}_{2} \mathrm{O}$ & 0.003 & 436 & 0 & 0 & 0 & 0 \\
\hline Ethylene Glycol & 0.0018 & 873 & 0 & 0 & 0 & 0 \\
\hline Total & 1 & 151082 & 1 & 136881 & 1 & 114834 \\
\hline
\end{tabular}


Table 12 Pant Production quantities for Ethane Recovery Mode.

\begin{tabular}{|c|c|c|c|c|c|c|c|c|}
\hline \multirow{2}{*}{ Raw Gas Rate } & \multirow{2}{*}{ Sales Gas } & \multicolumn{2}{|c|}{ Sales ethane } & \multicolumn{2}{|c|}{ Sales propane } & \multicolumn{2}{|c|}{ Sales LPG } & $\begin{array}{c}\text { Sales } \\
\text { Cond. } \\
\text { MMSCFD }\end{array}$ \\
\cline { 3 - 8 } & MMSCFD & $\begin{array}{c}\text { Ton/d } \\
\text { ay }\end{array}$ & Recovery \% & $\begin{array}{c}\text { Ton/d } \\
\text { ay }\end{array}$ & Recovery \% & $\begin{array}{c}\text { Ton/d } \\
\text { ay }\end{array}$ & Recovery \% & $\begin{array}{c}\text { RB } \\
\text { y }\end{array}$ \\
\hline 160 & 140.8 & 391.0 & 95.20 & 196.1 & 99.80 & 128.1 & 96.00 & 4080 \\
\hline
\end{tabular}

Table 13 Economic study results for ethane recovery mode.

\begin{tabular}{|c|c|}
\hline Fixed Capital Investment, MM\$ & 97.82 \\
\hline Operating Cost, MM\$ & 4.57 \\
\hline Total Capital Investment, MM\$ & 100.76 \\
\hline Revenue, MM\$ & 412.73 \\
\hline Increment, MM\$ & 64.38 \\
\hline ROI (return on investment), \% & 59 \\
\hline Pay-Back Time, Years & 1.68 \\
\hline
\end{tabular}

\section{Feed Stability Continuity}

Referring to the annual report of El Wastani company production gas figures and according to Figure 2 which represents the trend of raw gas rate at the inlet of the central processing facilities [30], as well as the average gas rate during the period from July 1, 2012 to March 1, 2013 [31], it is obtained that the average inlet gas rate stability is ranging from 140 to 158 MMscfd.
As shown in Figure 2, it is obvious that the average gas rate production in more conservative terms varies around 149 MMSCFD, so the feed stability term will be determined as a percentage of the required feed gas rate to the expected or average gas rate. According to the fuzzy logic system, the feed rate quantities are revalued to be compatible with the concept of fuzzy membership rule. So, the feed rate quantities are normalized as a fraction of the original capacity (160 MMSCFD), as shown in table 14

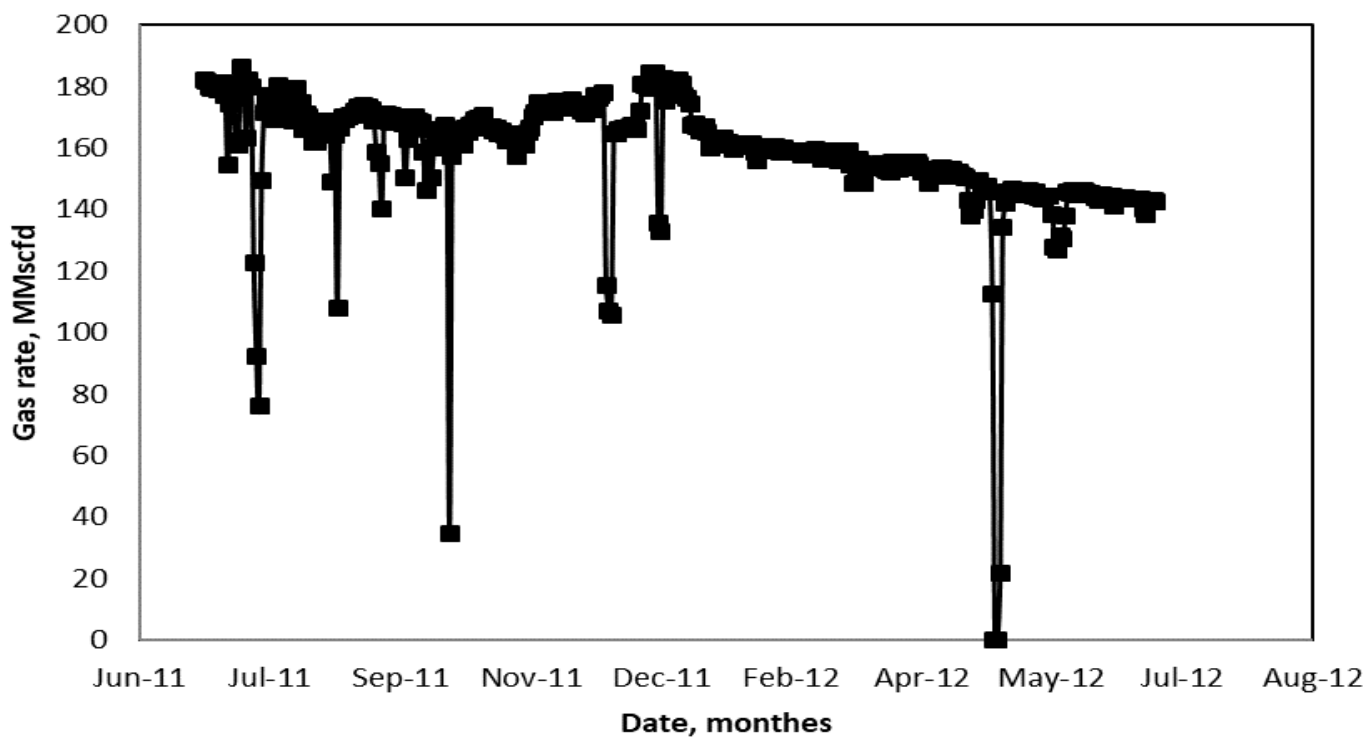

Figure 2 El-Wastani raw gas rate, MMSCFD [30].

Table 14 Normalized value of Feed Stability.

\begin{tabular}{|c|c|c|c|c|}
\hline Mode & Ethane & Propane & Butane & 200 MMscfd Mode \\
\hline Feed stability value & $(149 / 160)=0.9$ & $(149 / 160)=0.9$ & $(149 / 160)=0.9$ & $(149 / 200)=0.75$ \\
\hline
\end{tabular}

\section{Marketing Availability}

Plant products marketing availability is a very crucial objective and how easily these products could be sold and shipped are important factors in the economics of the plant. Figure 3 represents a promising plan for petrochemical industry in Egypt which is consuming the various natural gas products. Thus, each alternative will be characterized according 
to the current circumstances as a rough approximation properly.

Where polypropylene industry (propane consuming section) is already established and the UGDC (United Gas Derivatives Company) export terminal is in vicinity to the central processing facility (CPF) of El Wastani plant, so the marketing likelihood of propane mode could be about $75 \%$. On the other hand, for ethane mode which is evaluated as a new born, it could be estimated to have a value of $50 \%$. This low value of marketing availability of ethane mode may be attributed to the needs to some construction for pipelines or supply transfer trucks. For both of butane and capacity increase (200 MMSCFD) modes the likelihood is taken as $100 \%$. This is because all of the production are domestically consumed and transfer infrastructure were already established.

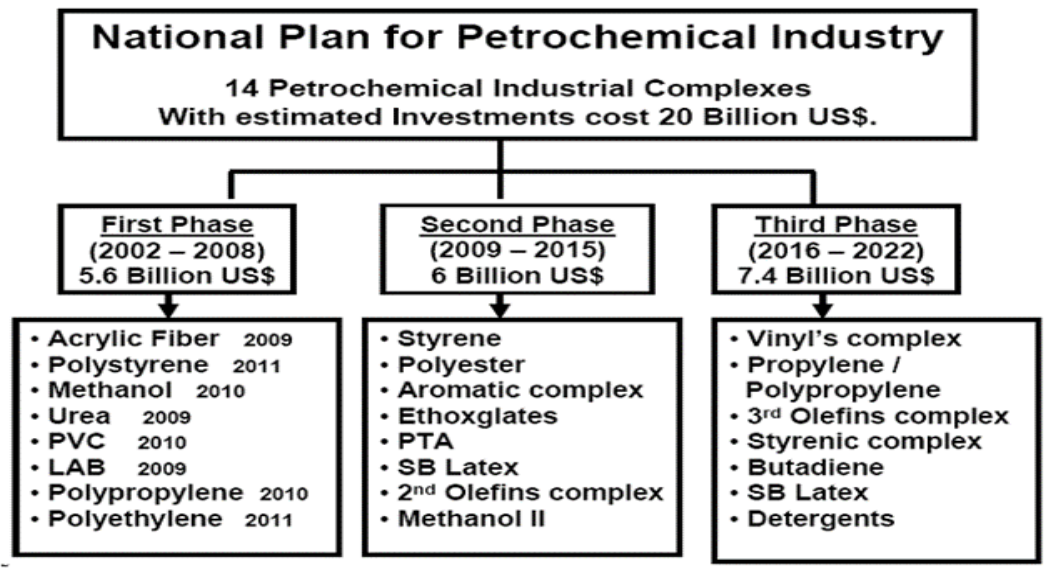

Figure 3 National plan for petrochemical industry in Egypt [32].

\section{Return on Investment}

Table 15 summarizes the different values of ROI for the four proposed improvement modes. The ROI values for high recovery of butane, propane or ethane modes are calculated according to the economic data Table 15 ROI Values for the four improvement modes.

\begin{tabular}{|c|c|}
\hline Alternative & ROI, \% \\
\hline 200 MMSCFD & 212 \\
\hline Ethane Mode & 59 \\
\hline Propane Mode & 133 \\
\hline Butane Mode & 56 \\
\hline
\end{tabular}

\section{Recovered Quantity of NGL}

NGL products are increasingly requested due to the vast raise in consuming sections such as domestic use, petrochemical plants, ..., etc. Thus, the availability and continuity of suppliers should be stable and should fulfill all national sections requirements. Therefore, the productivity improvements do not mainly relate to the profitability in money means, but previously presented in sections 3.1, 3.2, and 3.3. From this table, it is clear that operating the plant at 200 MMSCFD is the most profitable route based on its higher value of ROI.

Table 16 Various alternatives and objectives data tabulation.

\begin{tabular}{|c|c|c|c|c|}
\hline Alternative/Objective & $\begin{array}{c}\text { Feed } \\
\text { Stability }\end{array}$ & Marketing & $\begin{array}{c}\text { Total NGL Quantity, } \\
\text { Ton/day }\end{array}$ & ROI, \% \\
\hline 200 MMSCFD & 0.75 & Available & 814656 & 212 \\
\hline Ethane Mode & 0.9 & Available & 1182960 & 59 \\
\hline Propane Mode & 0.9 & Available & 766272 & 133 \\
\hline Butane Mode & 0.9 & Available & 681264 & 56 \\
\hline
\end{tabular}

\section{Data Mapping and Decision Making}

According to fuzzy logic methodology mentioned previously in section 2.4.2, the mapped value of each also it is strategically very important to provide the required raw material and energy sources.

To accomplish the process of decision making, it is important to determine the different values of the various objectives as shown in Table 16. Results showed that ethane mode gives the highest quantity of NGL while the capacity increase route (200 MMSCFD) gives the highest value of ROI and the lowest value of feed stability.

alternative is determined and the results are presented in Table 17. 
Table 17 Decision making problem solving results.

\begin{tabular}{|c|c|c|c|c|c|c|}
\hline Alternative/Objective & Feed Stability & Marketing & $\begin{array}{c}\text { Total NGL Quantity, } \\
\text { Ton/day }\end{array}$ & ROI, \% & Min. & Max. \\
\hline 200 MMscfd & 0 & 1 & 0.3 & 1 & 0 & \\
\hline Ethane Mode & 1 & 1 & 1 & 0.02 & 0.02 & \\
\hline Propane Mode & 1 & 1 & 0.2 & 0.5 & 0.2 & 0.2 \\
\hline Butane Mode & 1 & 1 & 0 & 0 & 0 & \\
\hline
\end{tabular}

Due to the results of the decision making process listed in Table17, it is clear that the optimum selection is propane mode route which make the plant more efficient and more profitable.

\section{Conclusions}

The present work results showed that the simple decision making methods rely only on ROI only exhibit that the capacity increasing route is more favorable for El Wastanti petroleum Company to increase its profitability and productivity. But by applying an intelligent system such as fuzzy logic technique, the plant can be more profitable by other routes rather than capacity route. From the economic and strategic viewpoints, it's more profitable to enhance the recovery of NGLs components; specially ethane and propane to assure utilizing of plant full capacity all the time, as well as to optimize the production rate from the wells network based on long productivity plan. So the present work studied new routes for the plant enhancement such as the maximization of butane, propane or ethane recovery.

The process of multi-objective decision making using fuzzy logic system showed that the maximization of propane recovery is the optimum and valuable route for improving El Wastani plant. This choice does not only depend on the higher value of $\mathrm{ROI}$ but takes into account other various objectives such as feed stability, marketing availability and recovered NGL quantity.

The efforts done in this present work are helpful and can be applied for improving the existing NGL recovery plants as well as the plants under design.

\section{References}

[1] M. S. M. Saliem, A. A. Bhran, G. M. A. Abdel-Aleim, A. A. Hady, Process Simulation and Performance Improving of an Existing NGL Plant, Faculty of Petroleum and Mining Engineering Journal 2012, 15,18-30.

[2] T. L. Joe, D. W. John, M. H. Hank, N. P. Richard, Process retrofits maximize the value of existing NGL and LPG recovery plants, Ortloff Engineers, Ltd. 2003, Midland, Texas.

[3] T. L. Joe, R. N. Pitman, Improving throughput and ethane recovery at GPM's Goldsmith gas plant, 75 Annual convention of the gas processors association, Denver, Colorado, 1996.
[4] L.Roger, J.Chen, Retrofit for NGL recovery performance using a novel stripping gas refrigeration schem, IPSIIIc, Hostune, Texas USA, 2007.

[5] M. Mehrpooya, F. Charagheizi, A. Vatani, An optimization of capital and operating alternatives in a NGL recovery unit, Chemical Engineering and Technolgy 2006, 29, 1469-1480.

[6] D. H. Mackenzie, S. T. Donnelly, Mixed refrigerant proven efficient in natural-gas-liquids recovery process, Oil \&Gas Journal 1985, 83, 116-120.

[7] M. Mehrpooya, A. Vatani, A. Mousavian, Introducing a novel integrated NGL recovery process configuration (with a self-refrigeration system (open-closed cycle)) with minimum energy requirement, Chemical Engineering and Processing: process intensification 2010, 49, 376-388.

[8] A. H Enriquez, J-K. Kim, Techno-Economic Design and Optimization of NGL Plant: A Retrofit Study, AIChE Spring Meeting, $9^{\text {th }}$ Topical Conference on Natural Gas Utilization, Tampa, Florida, April 26-30, 2009.

[9] J.G. Gulsby, Options for ethane rejection in the cryogenic expander plant, Houston Regional GPA Meeting, November 18, 1982.

[10] S. Mokhatab, W. A. Poe, J. G. Speight, Handbook of natural gas transmission and processing, Elsevier, 2006.

[11] R. H. Perry, Chemical engineers handbook, $6^{\text {th }}$ edition, McGraw Hill, 1997.

[12] S. P. Max, D. T. Klaus, Plant design and economics for chemical engineers, Fourth edition, McGraw-Hill, 1991.

[13] R. B. Carl, Rules of thumb for chemical engineers a manual of quick accurate solutions to everyday process engineering problems, Fourth edition, Elsevier, 2005.

[14] Material department of El-Wastani petroleum company, Purchased order of phase-3, Damietta, Egypt, 2005.

[15] E. Khabibullin, F. Febrianti, J. Sheng, S. Bandyopadhyay, Et al, "Process Design and Economic Investigation of LPG Production from Natural Gas Liquids (NGL)", NTNU, TKP4170 Process design project, 2010.

[16] A. M. A. Harron, Modification of the process of LPG production from natural gas in el-Qar'aa LPG plant, Master thesis, Cairo university, Cairo, 2000.

[17] A Größler, A content and process view on bounded rationality in system dynamics. Systems Research and Behavioral Science 2004, 21, 319-330.

[18] L. Wang, A course in fuzzy systems and control, Prentice-Hall, New Jersey, 1997.

[19] G.J. Klir, B Yuan. Fuzzy sets and fuzzy logic, PrenticeHall, New Jersey, 1995.

[20] R. R. Yager, Multiple objective decision-making using fuzzy sets, International journal of Man-Machine studies 1977, 9, 375-382. 
[21] H.-J. Zimmermann, Fuzzy set theory, WIREs Computational Statistics2010, 2, 317-332.

[22] R. E. Bellman, L. A. Zadeh, Decision making in a fuzzy environment, Management Science1970, 17,141-164.

[23] G. Chen, T. T. Pham, Introduction to fuzzy sets, fuzzy logic, and fuzzy control systems, CRC Press LLC, USA, 2001.

[24] L.A. Zadeh, Fuzzy sets as a basis for a theory of possibility, Fuzzy Sets and Systems1978, 1, 3-28.

[25] C. Carlsson, R. Fuller, Fuzzy multiple criteria decision making: Recent Developments, Fuzzy Sets and Systems 1996, 78, 139-153.

[26] M. Demirci, Fuzzy functions and their fundamental properties, Fuzzy Sets and Systems 1999, 106, 239-246.

[27] K. L. Jibril, A. I. Al-Humaizi, A. A. Idriss, A. A. Ibrahi, Simulation of turbo-expander process for recovering of natural gas liquids from natural gas, Saudi Aramco Journal of Technology, Fall 2005, 9-14.

[28] L. Fernandez, J. A. Bandoni, A. M. Elicehe, E. A. Brignole, Optimization of ethane extracting plants from natural gas containing carbon dioxide, Gas Separation and Purification1991, 5, 229-234.

[29] M. S. Diaz, A. Serani, J. A. Bandoni, E. A. Brignole, Automatic design and optimization of natural gas plants, Industrial \& Engineering Chemistry Research 1997, 36, 2715-2724.

[30] M. S. M. Saliem, Annual production report of El-Wastani Petroleum Company 2011/2012, Damietta, Egypt 2012.

[31] WASCO sale gas metering station daily reports, Damietta, Egypt.

[32] Ministry of Petroleum \& Mineral Resources, Egypt \& Business Monitor International Ltd. 